\title{
Natural diet and grazing rate of the temperate sponge Dysidea avara (Demospongiae, Dendroceratida) throughout an annual cycle
}

\author{
Marta Ribes*, Rafel Coma, Josep-Maria Gili \\ Institut de Ciències del Mar (CSIC), Passeig Joan de Borbó s/n, E-08039 Barcelona, Spain
}

\begin{abstract}
Sponges are one of the major invertebrate groups inhabiting hard-bottom communities worldwide. In this study, we measured in situ rates of grazing on DOC (dissolved organic carbon), POC (particulate organic carbon), and pico-, nano- and microplankton for the common temperate sponge Dysidea avara throughout a yearly cycle. The natural diet of the species was highly heterogeneous and included procaryotes (heterotrophic bacteria, Prochlorococcus sp., Synechococcus sp.) and eucaryotes (protozoa, phytoplankton, and ciliates) ranging in size from $0.5 \pm 0.3$ (heterotrophic bacteria) to $70 \pm$ $0.3 \mathrm{\mu m}$ (pennate diatoms). Procaryotic cell clearance rates were higher than those for the other groups, suggesting a higher grazing efficiency upon these prey types. Specific clearance rates showed a pattern of decrease with sponge size increase, although they did not vary with prey concentration or with temperature. Overall, procaryotes contributed $74 \pm 14 \%$ of the total ingested carbon, pico- and nanoeucaryotes contributed $11 \pm 3 \%$, and phytoplankton contributed $11 \pm 10 \%$. Therefore, Dysidea avara obtained $85 \%$ of its ingested carbon from the fraction smaller than $5 \mu \mathrm{m}$ and $15 \%$ from the fraction larger than $5 \mu \mathrm{m}$. However, the partial contributions of the different groups varied seasonally, following the planktonic composition of the water column. During winter, phytoplankton was an important component of the total uptake (26\%), whereas during the rest of the year it contributed less than $7 \%$ of the total uptake. The capacity of this sponge to feed on a broad size range of prey allowed it to maintain rather constant food uptake throughout the year. These results show the importance of particle type (size) for selective uptake in sponges, as well as the relevance of phytoplankton in the sponge diet. This trophic plasticity may represent an advantage for the species because it attenuates the effects of seasonal fluctuations in the planktonic community. This plasticity in trophic ecology may be one of the main factors contributing to the worldwide abundance and distribution of sponges despite large spatial and temporal variations in food sources.
\end{abstract}

KEY WORDS: Suspension feeding $\cdot$ Natural diet $\cdot$ Grazing rate $\cdot$ Prey selection $\cdot$ Sponges $\cdot$ Dysidea avara Mediterranean Sea

\section{INTRODUCTION}

Recent studies show that some benthic suspension feeders play a crucial role in energy transfer processes in coastal marine ecosystems (e.g. Cloern 1982, Officer et al. 1982, Kimmerer et al. 1994, Gili \& Coma 1998). In this regard, attention should be paid to those suspension feeders responsible for the coupling of the pelagic and benthic systems. However, most of this work has been carried out on molluscan populations dwelling on soft bottoms, and little is known about dense suspen-

·E-mail: mribes@icm.csic.es sion-feeder populations on hard substrates (but see Pile et al. 1997).

Sponges are one of the major invertebrate groups inhabiting hard-bottom communities worldwide. They filter large volumes of water (up to $1 \mathrm{l}$ per hour and $\mathrm{cm}^{3}$ of body volume, Reiswig 1971), with retention efficiencies between 75 and 99\% (Reiswig 1971, 1975, Wilkinson 1978, Pile et al. 1996). Past and present studies have shown that grazing rates of some sponges are within the same range 29 to $1970 \mathrm{mg} \mathrm{C} \mathrm{m}^{-2} \mathrm{~d}^{-1}$, Reiswig 1974, 1981, Pile et al. 1996, 1997) as in certain molluscan species ( 9 to $3621 \mathrm{mg} \mathrm{C} \mathrm{m} \mathrm{m}^{-2} \mathrm{~d}^{-1}$, see Criffiths \& Griffiths 1987 for review). Therefore, abundant 
sponge populations may exert an important grazing impact on their habitats. Despite the importance of sponges in a number of ecosystems, the diversity of forms, and the many different habitats they occupy, diet and grazing rates of sponge species under natural conditions are still poorly known.

Laboratory experiments, indirect measurements of particle uptake, and sampling of ambient and exhalant water samples collected in situ have shown that sponges can feed on a wide spectrum of food sources (Reiswig 1971, Frost 1987, Pile et al. 1996). This variety of food sources ranges from dissolved organic carbon (DOC) to phytoplankton (Schmidt 1970, Frost 1987), and in extremely food-poor environments even zooplankton can be captured (Vacelet \& Boury-Esnault 1995). However, the main research effort on sponge feeding has focussed on plankton $<2 \mu \mathrm{m}$, both in laboratory studies (van der Vyver et al. 1990, Riisgård et al. 1993, Turon et al. 1997) with artificial food and in field studies with natural diets (Reiswig 1971, 1975, Pile et al. 1996, 1997). This is due to the morphological characteristics of the filtration mechanisms, which, based on fine canals and groups of flagellate choanocytes, are able to capture particles smaller than $2 \mu \mathrm{m}$ very efficiently (Simpson 1984). Nevertheless, as already pointed out above, sponges can feed on plankters larger than $2 \mu \mathrm{m}$. Pinacocytes along the extensive canal system allow sponges to ingest sestonic particles as large as the diameter of the ostia (Reiswig 1971, Frost 1981, Gaino et al. 1994). Particles larger than the diameter of the ostia can be retained and picked up by the surface epithelium (Simpson 1984, Vacelet \& Boury-Esnault 1995).

Therefore, due to the observed wide range of food sources on which sponges can potentially feed, an accurate evaluation of the natural diet needs to include the entire available food spectrum. Available food in the water column is a continuum from DOC to the larger forms of particulate organic carbon, including both live carbon (bacteria, Prochlorococcus sp., cyanobacteria, protozoa, phytoplankton and zooplankton) and detrital organic carbon, although under normal circumstances zooplankton may be disregarded. Furthermore, because plankton communities exhibit strong temporal variability in temperate seas, feeding studies should be carried out seasonally.

In the Mediterranean Sea, seasonal variations in environmental factors such as temperature, food availability (Ribes 1998), and photoperiod (Zabala \& Ballesteros 1989) can cause important shifts in resource allocation by benthic modular organisms. In this regard, a summer paucity of seasonal species such as hydroids (Boero et al. 1986, Llobet et al. 1991) and regression in the activity of perennial species such as tunicates (Turon \& Becerro 1992), bryozoans (Zabala
1983), and gorgonians (Coma et al. 1998a) has been observed in the Mediterranean. The worsening of feeding conditions during the summer period due to a decline in phyto- and zooplankton abundance (Valentin 1972, Coma et al. 1994, Ribes 1998), as well as in current speed (Pasqual unpubl. data), has been suggested as the main reason for the regression or inactivity of the species at that time (Coma et al. 1998a). Knowledge of the diet of sponges and of seasonal variations in the diets could be used to test the general hypothesis that a trophic-energetic phenomenon underlies the summer regression by a sizeable number of Mediterranean species, for several reasons. Firstly, pico- and nanoplankton have been documented to be the main sources of particulate organic carbon (POC) for some sponge species (Reiswig 1971, Pile et al. 1996). Secondly, seasonal variations in these planktonic groups near the bottom have been observed to follow a rather different pattern from those of phyto- and zooplankton, with the lowest biomass during the winter period (Ribes 1998). Therefore, if the trophic-energetic phenomenon affects the abovementioned groups, and phyto- and zooplankton are not the main contributors to sponge diets, it could be postulated that sponge species should not exhibit the summer regression or inactivity.

In order to test this hypothesis we examined the trophic ecology of the Dendroceratida sponge Dysidea avara (Schmidt), a common and widely distributed temperate sponge species on sublittoral sciaphylous hard bottoms (Atlantic: Lombas 1982, Mediterranean: Uriz et al. 1992). D. avara is an epilithic species that develop between 10 and $40 \mathrm{~m}$ depth on a wide range of substrata, such as vertical walls, big boulders, at the entrance of caves, and between detrital debris. It grows among other sessile organisms, rarely forming monospecific patches. The rouncted colonies, between 5 and $15 \mathrm{~cm}$ across, irregularly encrust the rocks. They can also be found as lobulated masses up to about $20 \mathrm{~cm}$ in height. The surface of colonies is characteristically covered with conuli and is greyish white or brownish in color. The oscula are distinct and scattered, and the skeleton is a meshwork of spongin fibres without spicules. Consumption rates for this species on the different natural food sources (DOC, pico-, nano-, and microplankton, and detritus) were studied with in situ incubations on a seasonal basis in order to cover the natural range of food concentration in the water column.

\section{MATERIALS AND METHODS}

This study was conducted at the Medes Islands Marine Reserve (NW Mediterranean Sea, $42^{\circ} 3^{\prime} \mathrm{N}$, 
$3^{\circ} 13^{\prime}$ E) from October 1995 to November 1996. Incubations were conducted in hemispherical UV-transparent Plexiglas chambers approximately $3 \mathrm{l}$ in volume. The chambers ( 1 experimental, with sponge, and 1 control) were placed at $10 \mathrm{~m}$ depth by scuba divers. The chambers had an inlet and an outlet aperture connected to a common piece of PVC tubing, producing a closed system. An electric pump was placed at the outlet aperture which during normal operation forced water through the system at a speed of $1.2 \mathrm{~cm} \mathrm{~s}^{-1}$ (this flow became turbulent inside the chambers). Whole Dysidea avara specimens were removed together with a piece of substrate free of organisms and cleaned of any macroepibionts. Removed specimens were then transplanted back onto the substratum using an inert mastic compound (Scotch-Calk, as in Coma et al. 1996). The colonies were kept in their natural environment with conspecifics until used in the incubation experiments, which were performed in situ. At the beginning of each experiment, a $D$. avara colony was placed on the base of the experimental chamber and allowed to acclimatize for $1 \mathrm{~h}$. During this period, the inlet and outlet apertures were not connected, so that the system worked in an open-flow mode. Three replicate water samples of $500 \mathrm{ml}$ were collected from the outlets of both chambers (initial water samples) and preserved for further analysis (see below). At this point, inlet and outlet apertures were connected and the system was operated in closed-flow mode for $1 \mathrm{~h}$. Several experiments were conducted to determine the most suitable combination of sponge biomass and incubation time that optimized the detection of changes in prey concentration (prey changes need to be large enough to be accurately measured for all prey types). Also, the drop in oxygen concentration during the experiment was considered not to affect the respiration rate of the species and, therefore, its feeding behavior (Ribes unpubl. data). After the incubation period, the chambers were taken to the surface and 3 replicate water samples were collected again from both chambers (final water samples). Grazing was calculated from decreases in prey concentration in the experimental chamber relative to the control chamber. The potential prey items included: heterotrophic bacteria, Synechococcus sp., Prochlorococcus sp., autotrophic pico- and nanoeucaryotes, ciliates, phytoplankton (diatoms and dinoflagellates), DOC and detrital POC. Synechococcus sp. and Prochlorococcus sp. are autotrophic procaryotes. Prochlorococcus sp. are difficult to quantify by methods other than flow cytometry. Water volume used for the analysis of DOC, POC, and pico- and nanoeucaryotes was filtered through a $100 \mu \mathrm{m}$ mesh to remove larger plankters. Five experiments were carried out during each of the 4 seasons: winter (December 23, January 7, March 5, 8, and 9), spring (May 17, 21, 22, 25, and 26), summer (July 30, August 7, 8, and 10, September 5) and fall (September 30 , October $8,9,21$, and 22). Thus, a total of 20 experiments were performed over the yearly cycle.

Flow cytometry was used to quantify heterotrophic bacteria, Prochlorococcus sp., Synechococcus sp., picoand nanoeucaryotes. Water samples $(2 \mathrm{ml})$ from the incubation chambers were preserved for flow cytometry by standard protocols (Campbell et al. 1994) and frozen in liquid nitrogen; they were then stored at $-80^{\circ} \mathrm{C}$ or in dry ice. Samples were analyzed using a Coulter EPICS 753 flow cytometer (Coulter Electronics Corporation, Hialeah, Florida) equipped with two $5 \mathrm{~W}$ argon lasers and a Micro-Sampler-Delivery-System. The flow cytometer was set up for UV $(220 \mathrm{~mW})$ and $488 \mathrm{~nm}(1 \mathrm{~W})$ colinear analysis. Hoechst 33342 (DNAspecific fluorochrome) was used to stain DNA according to Monger \& Landry (1993). Five parameters were collected in list mode and analyzed with customdesigned software (CYTOPC by Daniel Vaulot): red fluorescence (from chlorophyll a), orange fluorescence (from phycoerythrin), blue fluorescence (from DNA stained with Hoechst 33342), and forward-and rightangle light scatter signals (FALS and RALS). For statistical purposes, sample size for analysis was chosen to provide more than 10000 events sample ${ }^{-1} ; \mathrm{ml}$ of water sample was analyzed for picoeucaryotes and nanoeucaryotes and $100 \mu \mathrm{l}$ for heterotrophic bacteria, Prochlorococcus sp., and Synechococcus sp. Flow cytometer and epifluorescence microscopy counts were compared in a previous study to validate flow cytometer use with our samples (Ribes 1998).

Subsamples of $20 \mathrm{ml}$ were stained with DAPI and retained on $0.2 \mu \mathrm{m}$ filters to measure the cell size (length and width) of heterotrophic bacteria, Synechococcus sp., and pico- and nanoeucaryotes. For heterotrophic bacteria size, $\geq 100$ cells were measured using image analysis software as described by Massana et al. (1997). For Synechococcus sp. and pico- and nanoeucaryotes, cell length and width were measured with an ocular micrometer. Picoeucaryotes included naked flagellates smaller than $2 \mu \mathrm{m}$ and nanoeucaryotes included naked flagellates larger than $2 \mu \mathrm{m}$ as well as small dinoflagellates (not discernible with an inverted microscope) and coccolithophores (uncountable with acid Lugol's) (see below). It was not possible to measure Prochlorococcus sp. size due to the difficulty in observing these cells with epifluorescence microscopy; a mean size of $0.7 \mu \mathrm{m}$ calculated for the Mediterranean by Vaulot et al. (1990) was therefore used.

To quantify phytoplankton and ciliates, $350 \mathrm{ml}$ water samples were preserved with acid Lugol's (1\% final concentration). Subsamples of $100 \mathrm{ml}$ were placed in settling chambers, and major groups of nano- and 
microphytoplankton were quantified under an inverted microscope. The microscope was provided with a color CCD video camera connected to a video recorder. Images of the organisms for measurement were recorded on tape and digitized with a frame grabber. Organism size was determined by image analysis software (NIH image). In each subsample, 20 individuals of the most common groups were measured. Volumes were estimated from the length and width measurements assuming ellipsoidal or cylindrical shapes (Edler 1979).

POC was measured by filtering $60 \mathrm{ml}$ water samples on pre-combusted GF/F glass fibre filters. Filters were then frozen in liquid nitrogen and kept at $-80^{\circ} \mathrm{C}$ until analysis. Prior to analysis, filters were dried at $60^{\circ} \mathrm{C}$ for $24 \mathrm{~h}$ and exposed to chloric acid vapors for $48 \mathrm{~h}$ to destroy inorganic material. The filters were then dried again and analyzed with a Perkin-Elmer $240 \mathrm{C}: \mathrm{H}: \mathrm{N}$ autoanalyser. Total particulate organic carbon measurements included both detrital and live carbon. Detrital organic carbon, hereafter detrital POC, was estimated as the difference between the total POC ( $\mathrm{C}: \mathrm{H}: \mathrm{N}$ analysis) and the total live carbon estimated from cell counts and cell measurements.

For DOC, $20 \mathrm{ml}$ water samples were filtered through pre-combusted GF/F glass fibre filters. The filtered water was stored in glass tubes at $-20^{\circ} \mathrm{C}$ until analysis. Analysis was conducted by high-temperature catalytic oxidation with a Shimadzu TOC-5000 autoanalyser.

Depletion rates were calculated by assuming exponential growth and clearance of prey as described in Ribes et al. (1998). The significance of predation on each kind of prey was tested by comparing growth rates of prey in control and experimental chambers with a 2-tailed Wilcoxon test (Sokal \& Rohlf 1981).

Cell biovolume was calculated from length and width by approximation to the nearest geometric shapes. Carbon content was then estimated from literature conversion factors as follows: heterotrophic bacteria $0.22 \mathrm{pg} \mathrm{C} \mathrm{mm}^{-3}$ (Fry 1988); Prochlorococcus sp., $0.133 \mathrm{pg} \mathrm{C} \mathrm{mm}^{-3}$ (Simon \& Azam 1989); Synechococcus sp., $0.357 \mathrm{pg} \mathrm{C} \mu \mathrm{m}^{-3}$ (mean value of: Bjørnsen 1986, Kana \& Glibert 1987, Venty et al. 1992); pico-

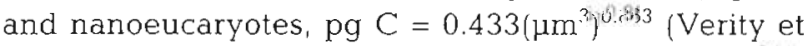
al. 1992); phytoplankton, pg C cell ${ }^{-1}=0.109\left(\mu \mathrm{m}^{3}\right)^{0.901}$ (Montagnes et al. 1994); and ciliates, $0.19 \mathrm{pg} \mathrm{C} \mu \mathrm{m}^{-3}$ (Putt \& Stoecker 1989).

Scanning electron microscope (SEM) observations of sponge tissue and of the filters for both the initial and final incubation water samples were carried out in order to look for direct evidence of captured prey items. Ten tissue samples from different non-incubated sponges and the initial and final water sample filters for 5 experiments were dehydrated in graded ethanol. Afterwards, the tissue and the filters were dried by the critical point method (using $\mathrm{CO}_{2}$ as transition fluid), mounted on aluminum stubs and coated with gold in a sputter coater. Observations were made with a Hitachi S-570 SEM.

Dysidea avara dry weight was determined by drying at $100^{\circ} \mathrm{C}$ for $24 \mathrm{~h}$, and ash free dry weight (AFDW) was determined by combustion at $500^{\circ} \mathrm{C}$ for $6 \mathrm{~h}$. Prior to combustion, sponges were rinsed to remove any salts and dissected to remove any associated macrofauna.

Multiple regression analysis was used to establish the percentage variance in the estimated clearance rates $(C R)$ that could be explained by 3 independent factors monitored during each experiment: water temperature $\left({ }^{\circ} \mathrm{C}\right.$, recorded using a WTW oxygen electrode model EOT 196), initial prey concentration ( $\mu \mathrm{g} \mathrm{Cl^{-1 } )}$ and sponge size (g AFDW). A backward stepwise procedure was used to exclude non-relevant variables (Sokal \& Rohlf 1981). Variables were square root transformed when requirements for normality (Kolmogorov-Smirnov test) and/or heteroscedasticity (Levene's test) were not fulfilled.

Two methods were employed to examine whether or not the species was selectively grazing on any proportion of the plankton community. First, the $C R_{\mathrm{AFDW}}$ equations estimated for each prey type were compared using analysis of covariance (ANCOVA). Second, the percentage of carbon in the diet of sponges was compared to the percentage of carbon in the plankton component using a $\chi^{2}$ test (Sokal \& Rohlf 1981).

\section{RESULTS}

The total organic carbon potentially available as a food resource for Dysidea avara at the study site was examined. The potential food sources included DOC, detrital POC, and live carbon (i.e. recognizable cells). For all experiments overall, the growth rates calculated for the control chamber and for the experimental chamber showed that Dysidea avara significantly depleted all live carbon groups and exhibited a net production of DOC (mean $\pm \mathrm{SE}: 0.33 \pm 0.15 \mathrm{mg} \mathrm{C} \mathrm{g}$ $\mathrm{AFDW}^{-1} \mathrm{~h}^{-1}$; Fig. 1)

Ash-free dry weight specific clearance rate values $\left(C R_{\text {AFDW, }}\right.$ ml swept clear $g \mathrm{AFDW}^{-1} \mathrm{~h}^{-1}$, hereafter specific clearance rate) (i.e. the volume of water that had to be filtered by the sponge to bring about the observed decrease in the number of cells, assuming $100 \%$ efficiency in particle retention) was seasonally calculated as the mean of the 5 experiments. For all experiments and prey types, the percentage decrease in prey concentration during the incubation was always less than $45 \%$ (Table 1 ). Oxygen concentration at the beginning of each experiment was always slightly supersaturated. The drop in oxygen concentration dur- 


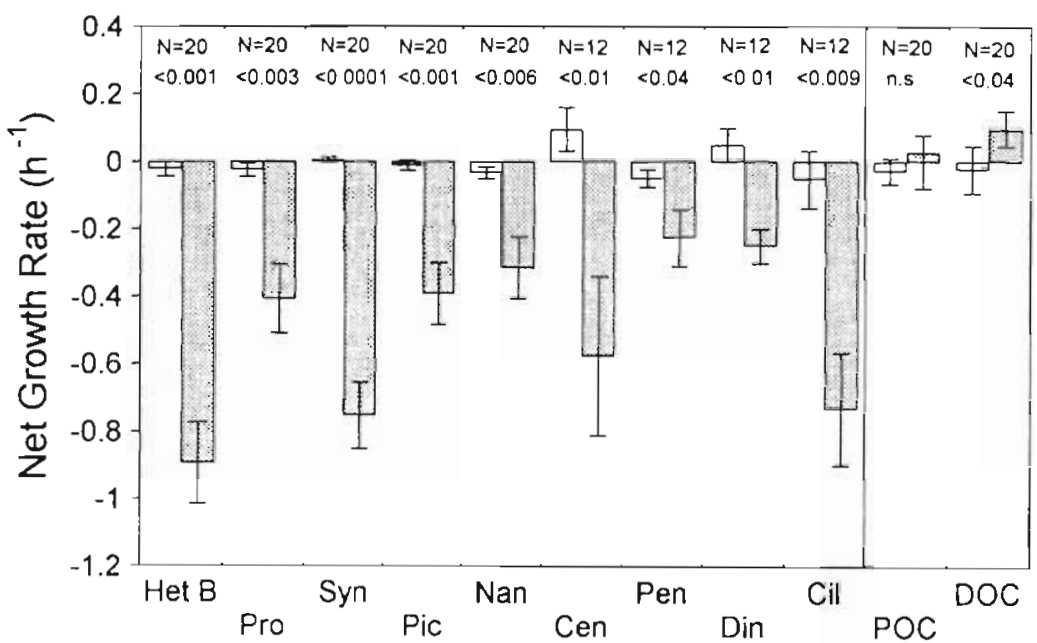

Fig. 1. Net growth rates of prey (mean $\pm \mathrm{SE}$ ) in the experimental (dotted bars) and control chambers (empty bars). Data are presented for each planktonic group: Het B: heterotrophic bacteria; Pro: Prochlorococcus sp.; Syn: Synechococcus sp.; Pic: autotrophic picoeucaryotes; Nan: autotrophic nanoeucaryotes; Cen: centric diatoms; Pen: pennate diatoms; Din: dinoflagellates; Cil: ciliates; POC: detrital particulate organic carbon; DOC: dissolved organic carbon Number of experiments and significance levels from the 2-tailed Wilcoxon test are also shown. n.s.: not significant

ing the experiments was never above $15 \%$ of the initial oxygen concentration; such a drop is generally known not to be physiologically limiting (Crisp 1984, Ribes unpubl. data). The $C R_{\text {AFDW }}$ for each season and prey type are shown in Fig. 2.

The experiments, carried out seasonally, encompassed the natural ranges of prey concentration (10 to $50 \mu \mathrm{g}$ live carbon $\left.\mathrm{l}^{-1}\right)$ and temperature $\left(12\right.$ to $23^{\circ} \mathrm{C}$; Ribes et al. 1998) at the study site throughout the year. Within these ranges, the study permitted comparison of the mean $C R_{\mathrm{AFDW}}$ for all prey types by sponge size (weight), prey concentration, and temperature. $C R_{\text {AFDW }}$ did not vary with prey concentration ( $\mu \mathrm{g}$ live carbon $\mathrm{l}^{-1}$ ) or with water temperature (multiple regression analysis, $n=20, p>0.5$ for both variables and all prey types). For all prey types, sponge size was the only variable that explained a significant proportion of the variance in $C R_{\text {AFDW }}$ (Table 2). The pattern of decrease in $C R_{\text {AFDW }}$ with sponge size was best fit by a power function (Table 2). This effect was highly pronounced for sponges below about $1 \mathrm{~g}$ AFDW, but the pattern was less distinct for sponges above this size (Fig. 3). The effects of prey concentration and temperature were examined for sponges larger than $1 \mathrm{~g}$ AFDW. $C R_{\text {AFDW }}$ did not vary within the natural ranges of prey concentration and temperature at the study site (multiple regression analysis, $\mathrm{n}=11, \mathrm{p}>0.2$ for both variables).

ANCOVA was used to examine whether or not $C R_{\mathrm{AFDW}}$ differed for the different prey groups, parameters ' $a$ ' and ' $b$ ' from the relationship between sponge size ( $S, g$ AFDW) and $C R_{\text {AFDW }}$ $\left(C R_{\mathrm{AFDW}}=a S^{b}\right)$ were compared among the different groups (Table 3 ). The relationship between $C R_{\text {AFI W }}$ and sponge size $(S)$ was significantly different among some prey groups. Although not statistically different from each other, $C R_{\mathrm{AFD}}$ for heterotrophic bacteria, Prochlorococcus sp., and Synechococcus sp. were significantly higher than the $C R_{A F D W}$ for pico- and nanoeucaryotes. $C R_{\mathrm{AFDW}}$ for pico- and nanoeucaryotes did not differ from each other but were significantly higher than the $C R_{\text {AFDW }}$ for diatoms, dinoflagellates, and ciliates (Table 3). Overall, the variation in $C R_{\mathrm{AFDW}}$ among prey types suggests an inverse relationship between prey size and $C R_{\mathrm{AFDW}}$.

Ingestion rate $(I)$ was calculated as a function of clearance rate $(C R)$ and prey concentration $(C)(I=C R \times C$; see Ribes et al. 1998b for further details). Due to the dependence of clearance rate on sponge size, the amount of carbon seasonally ingested was estimated for the 2

Table 1. Seasonal prey concentration (mean \pm SD; Het B, Pro, Syn, Pic, Nan: $10^{3}$ cells ml ${ }^{-1}$; Diatoms, Din, Cil: $10^{3}$ cells $1^{-1}$ ). $\%$ change: percentage decrease in prey concentration in the final water samples with respect to the initial concentration. Prey abbreviations as in Fig. 1, except Diatoms, which includes centric and pennate diatoms

\begin{tabular}{|c|c|c|c|c|c|c|c|c|}
\hline Prey & \multicolumn{2}{|c|}{ Summer } & \multicolumn{2}{|c|}{$\begin{array}{l}\text { Fall } \\
\text { Concentration \% change }\end{array}$} & \multicolumn{2}{|c|}{$\begin{array}{c}\text { Winter } \\
\text { Concentration \% change }\end{array}$} & \multicolumn{2}{|c|}{$\begin{array}{l}\text { Spring } \\
\text { Concentration } \% \text { change }\end{array}$} \\
\hline Het B & $339 \pm 88$ & $34 \pm 14$ & $349 \pm 128$ & $41 \pm 16$ & $465 \pm 139$ & $27 \pm 3$ & $361 \pm 107$ & $42 \pm 7$ \\
\hline Pro & $2.69 \pm 1.94$ & $26 \pm 15$ & $23.06 \pm 15.11$ & $24 \pm 17$ & $1.68 \pm 0.36$ & $16 \pm 7$ & $1.54 \pm 0.61$ & $36 \pm 4$ \\
\hline Syn & $16.45 \pm 5.73$ & $33 \pm 12$ & $30.06 \pm 18.50$ & $31 \pm 15$ & $9.20 \pm 3.54$ & $29 \pm 4$ & $10.45 \pm 6.11$ & $42 \pm 7$ \\
\hline Pic & $0.79 \pm 0.51$ & $11 \pm 15$ & $1.13 \pm 0.34$ & $29 \pm 17$ & $1.93 \pm 0.81$ & $27 \pm 3$ & $0.99 \pm 0.337$ & $33 \pm 7$ \\
\hline Nan & $0.30 \pm 0.25$ & $11 \pm 14$ & $0.36 \pm 0.17$ & $21 \pm 14$ & $0.40 \pm 0.17$ & $18 \pm 4$ & $1.05 \pm 0.58$ & $37 \pm 5$ \\
\hline Diatoms & $10.01 \pm 0.20$ & $14 \pm 3$ & $14.70 \pm 0.46$ & $17 \pm 13$ & $100 \pm 20$ & $16 \pm 2$ & $43.02 \pm 15.70$ & $22 \pm 18$ \\
\hline Din & $1.79 \pm 0.70$ & $2 \pm 1$ & $1.78 \pm 0.74$ & $13 \pm 9$ & $2.57 \pm 0.44$ & $12 \pm 9$ & $3.51 \pm 2.64$ & $13 \pm 10$ \\
\hline Cil & $0.14 \pm 0.06$ & $17 \pm 14$ & $0.22 \pm 0.07$ & $26 \pm 21$ & $0.21 \pm 0.04$ & $29 \pm 2$ & $0.27 \pm 0.08$ & $45 \pm 2$ \\
\hline
\end{tabular}



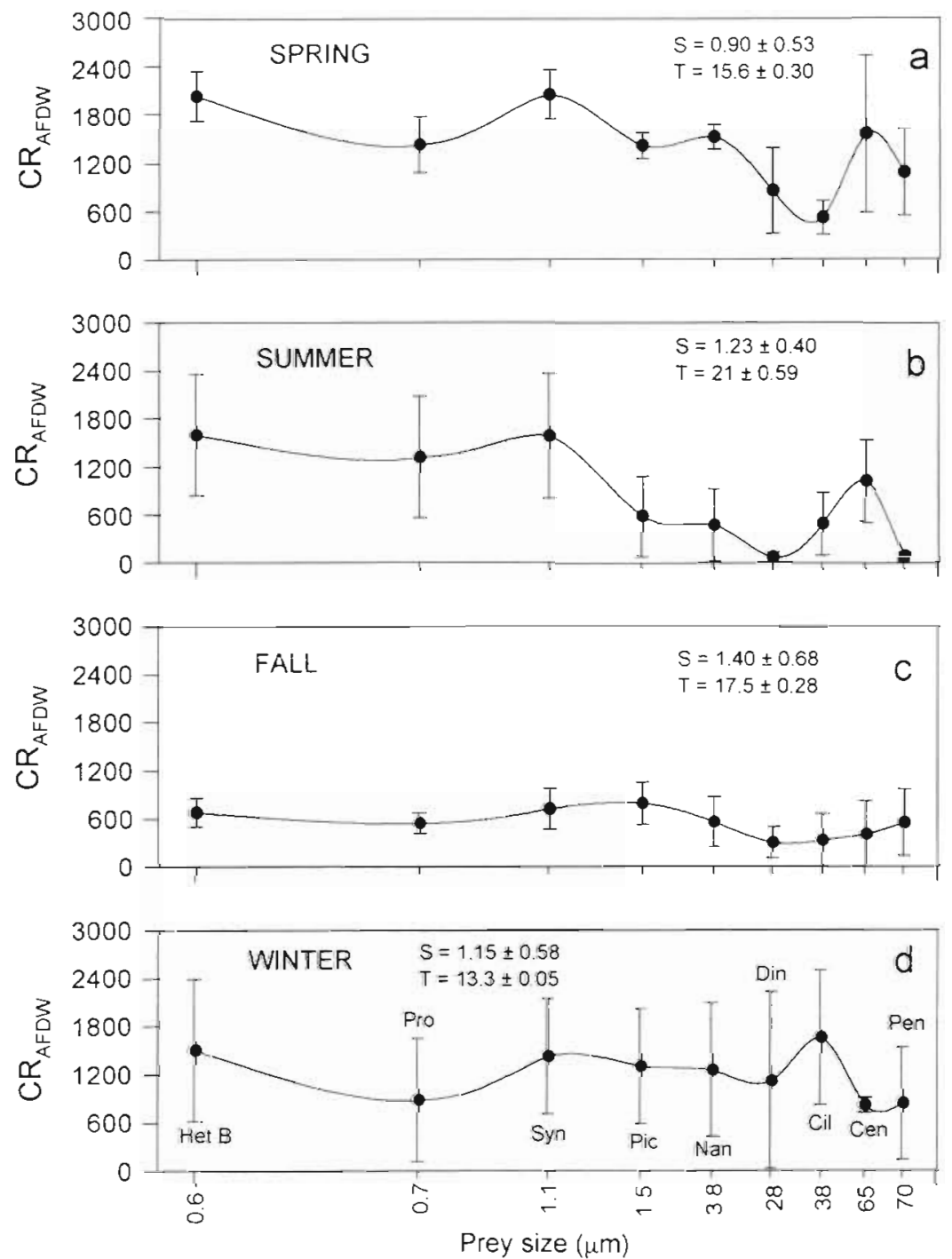

Fig. 2. Dysidea avara. Seasonal specific clearance rates $\left(C R_{A D F w i} \mathrm{ml}\right.$ swept clear $g$ AFDW $W^{-1} h^{-1}$, mean $\pm \mathrm{SE}$ ) as a function of prey size $(\mu \mathrm{m})$. Prey size on log scale. $S$ : mean $\pm \mathrm{SD}$ sponge size (g AFDW) used in the 5 experiments; $T$ : mean $\pm \mathrm{SD}$ water temperature $\left({ }^{\circ} \mathrm{C}\right)$. Prey abbreviations as in Fig. 1 and time $\left(10\right.$ to $12 \mu \mathrm{g} \mathrm{Cg} \mathrm{AFDW}{ }^{-1} \mathrm{~h}^{-1}$ : Table 4). Overall, procaryotes (i.e. heterotrophic bacteria, Prochlorococcus sp., and Synechococcus sp.) contributed $74 \pm 14 \%$ of the total ingested carbon, pico- and nanoeucaryotes contributed $11 \pm 3 \%$, and phytoplankton contributed $11 \pm 10 \%$. Thus, Dysidea avara obtained $85 \%$ of the ingested carbon from the fraction smaller than $5 \mu \mathrm{m}$ and $15 \%$ from the fraction larger than $5 \mu \mathrm{m}$. However, partial contributions by the different groups varied throughout the year. The highest phytoplankton contribution to the carbon ingested by the sponge, mainly diatoms, was observed during the winter period (phytoplankton: $26 \%$, procaryotes: $57 \%$; Table 4). Overall, the heterogeneous diet of the species and its capacity to feed on a wide range of prey sizes allowed the species to maintain rather constant levels of food uptake throughout the year (Table 4 ).

The proportion of ingested carbon from the different prey types was statistically different from levels for the water column community (summer: $\chi^{2}=62.24$, fall: $\chi^{2}=103.84$, winter: $\chi^{2}=215$, spring: $\chi^{2}=135.4$ idf $=7, \mathrm{p}<$ 0.0001 for all seasons). These differences were due to the fact that procaryotes were captured in greater proportion than their frequency in the plankton. Furthermore, the increase in the contribution by phytoplankton to the pool of live carbon in the water column during the winter period was not ingested in the same proportion by the sponge (Table 4). extreme sizes tested during the experiments ( 0.2 and $1.6 \mathrm{~g}$ AFDW). Seasonal carbon ingested by the species was calculated by applying the specific clearance rate for each prey type (Table 2) to the seasonal mean prey concentration values for the study area (Ribes 1998). Thus, a Dysidea avara colony $0.2 \mathrm{~g}$ AFDW in size ingested between 169 and $183 \mu \mathrm{g} \mathrm{Cg} \mathrm{AFDW} \mathrm{C}^{-1} \mathrm{~h}^{-1}$, depending on the season (Table 4). A colony $1.6 \mathrm{~g}$ AFDW in size ingested 1 order of magnitude less carbon per unit of biomass
Table 2. Dysidea avara. Relationship between specific clearance rate $\left(C R_{\mathrm{ADFw}}\right.$; $\mathrm{ml}$ swept clear $\mathrm{g} A F D W^{-1} \mathrm{~h}^{-1}$ ) and sponge size ( $\mathrm{S}, \mathrm{g}$ AFDW). $\mathrm{n}$ : number of cases

\begin{tabular}{|llccc|}
\hline Prey & Power function & $\mathrm{r}$ & $\mathrm{p}$ & $\mathrm{n}$ \\
\hline Heterotrophic bacteria & $C R_{\text {AFDW }}=1276 \times S^{-1.04}$ & 0.84 & $<0.0001$ & 20 \\
Prochlorococcus sp. & $C R_{\text {AFDW }}=1157 \times S^{-1.16}$ & 0.83 & $<0.0001$ & 20 \\
Synechococcus sp. & $C R_{\text {AFDW }}=1321 \times S^{-0.95}$ & 0.83 & $<0.0001$ & 20 \\
Picoeucaryotes & $C R_{\text {AFDW }}=854 \times S^{-1.15}$ & 0.91 & $<0.0001$ & 20 \\
Nanoeucaryotes & $C R_{\text {AFDW }}=770 \times S^{-1.29}$ & 0.92 & $<0.0001$ & 20 \\
Diatoms & $C R_{\text {AFDW }}=537 \times S^{-0.96}$ & 0.51 & 0.023 & 12 \\
Dinoflagellates & $C R_{\text {AFDW }}=176 \times S^{-2.29}$ & 0.73 & 0.012 & 12 \\
Ciliates & $C R_{\text {AFDW }}=676 \times S^{-1.03}$ & 0.54 & 0.013 & 12 \\
\hline
\end{tabular}



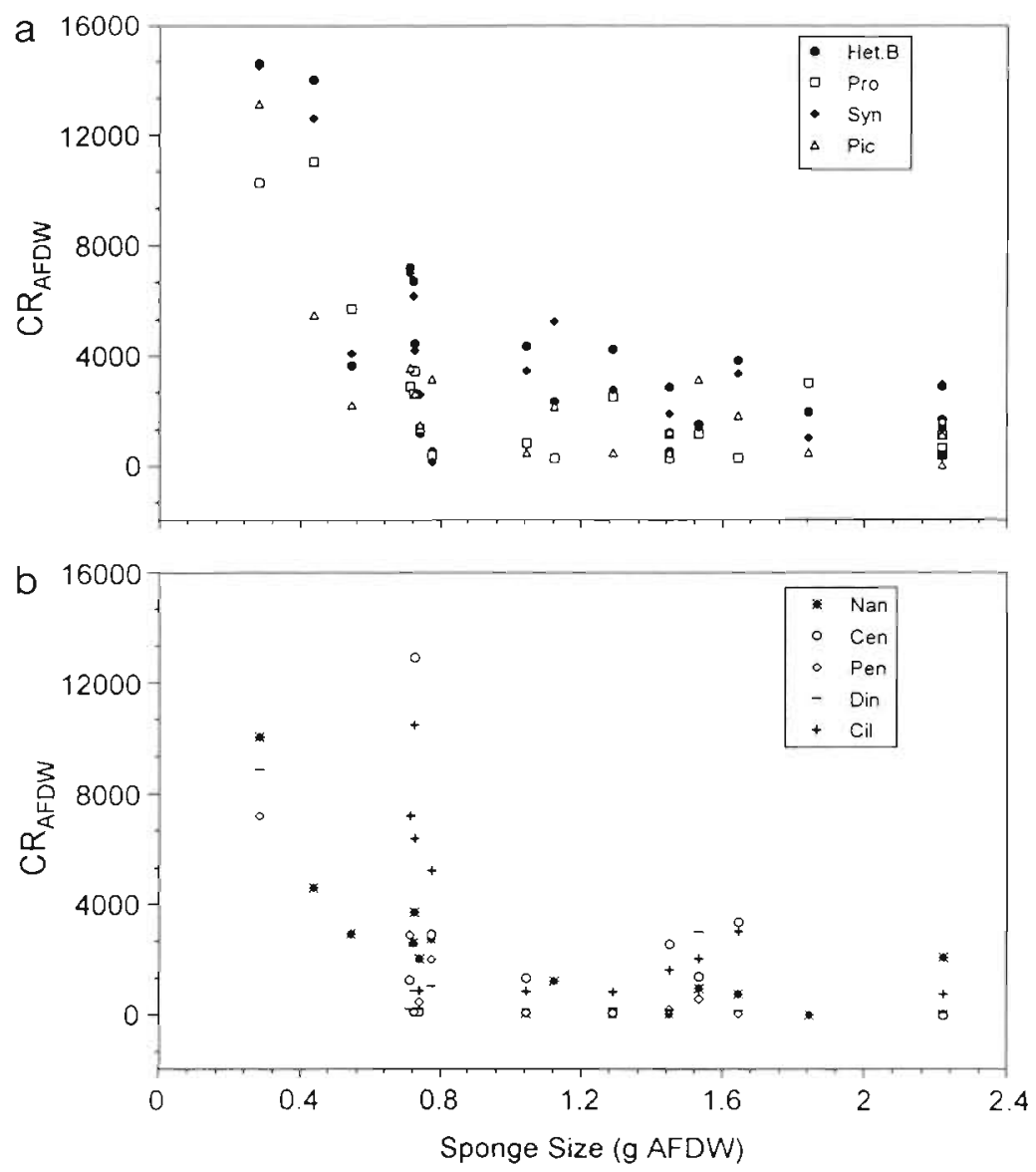

Fig. 3. Dysidea avara. Relationship between sponge size (g AFDW) and specific clearance rates $\left(C R_{\text {ADFw; }} \mathrm{ml}\right.$ swept clear $\left.\mathrm{AFDW} \mathrm{W}^{-1} \mathrm{~h}^{-1}\right)$. (a) Heterotrophic bacteria (Het B), Prochlorococcus sp. (Pro), Synechococcus sp. (Syn), picoeucaryotes (Pic). (b) Nanoeucaryotes ( $\mathrm{Nan}$ ), centric diatoms (Cen), pennate diatoms (Pen), dinoflagellates (Din), ciliates (Cil)

SEM observations of sponge tissue showed many trapped phytoplankton in differing stages of digestion. None of the phytoplanktonic remains were larger than $30 \mu \mathrm{m}$. SEM observations of the filters from the final incubation water samples showed a large number of pseudopellets (between 5 and $50 \mu \mathrm{m}$ ) (Fig. 4a) in which different phytoplanktonic remains such as diatoms and coccolithophores were identified (Fig. 4b). None of the filters from the initial incubation water samples contained such pseudopellets.

\section{DISCUSSION}

The diet of Dysidea avara was highly heterogeneous and included heterotrophic bacteria, Prochlorococcus sp., Synechococcus sp., pico- and nano- eucaryotes, and microplankton. This heterogeneous diet represented a broad size spectrum of food sources, from values of $0.5 \pm 0.3$ (heterotrophic bacteria) to $70 \pm 22 \mu \mathrm{m}$ (pennate diatoms). The ability of sponges to efficiently capture picoplankton (plankton $<2 \mu \mathrm{m}$ ) has been well documented (e.g. Reiswig 1971, Pile et al. 1996), but fewer data are available on the capture of large cells such as phytoplankton (but see Reiswig 1971, Frost 1981).

Estimated clearance rates varied among some prey types, suggesting an inverse relationship between mean prey size and clearance rate. This result indicates that the smallest prey types were retained with higher efficiency, showing the ability of the species to select particles. The mean diameter of the ostia for Dysidea avara (30 $\mu \mathrm{m}$, Turon et al. 1997) allows the capture of all studied prey items except diatoms. Recent laboratory experiments with D. avara carried out with latex beads showed that particles from 0.2 to $4 \mu \mathrm{m}$ were retained in the choanocytes and that particles larger than $6 \mu \mathrm{m}$ were captured by the pinacocytes; prey about $1 \mu \mathrm{m}$ in size were captured most efficiently (Turon et al. 1997), in agreement with our study.

Pinacocytes are found in the inhalant aquiferous systems as well as on the epidermis of the sponge. Diatoms, or other cells $>30 \mu \mathrm{m}$ in size, can be phagocytosed by pinacocytes upon contact with several surfaces of the sponge (Conover 1981). As pointed out before, a portion of the differences in the ingested carbon values for the different groups and their proportions in the water

Table 3. Dysidea avara. Results of ANCOVA comparing specific clearance rates $\left(C R_{A F D W}\right)$ as a function of sponge size ( $S, \mathrm{~g}$ AFDW) for the different prey groups on In-transformed data. n: number of cases. Prey abbreviations as in Fig. 1, except Diatoms, which includes centric and pennate diatoms

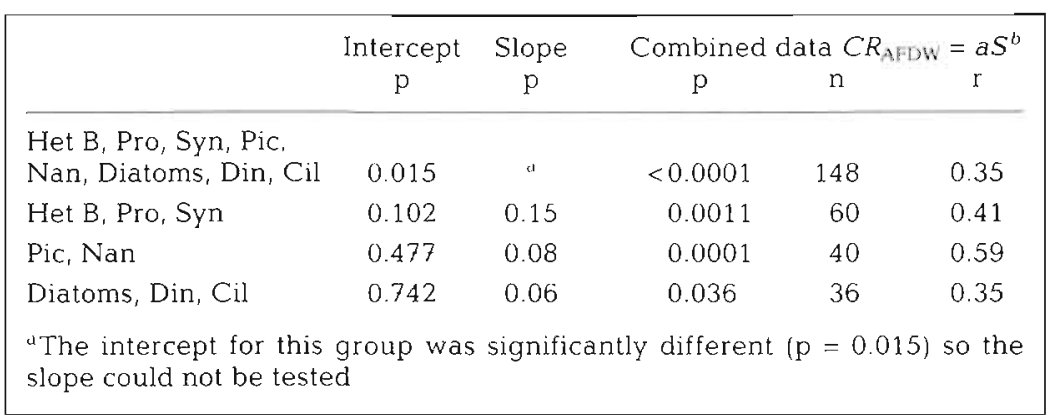


Table 4. Dysided avara. Seasonal estimated ingestion rates $\left(\mu \mathrm{g} \mathrm{Cg}\right.$ AFDW $\left.{ }^{-1} \mathrm{~h}^{-1}\right)$. Values have been estimated for the extreme sizes examined during the experiments (0.2 and $1.6 \mathrm{~g}$ AFDW). \% diet: prey composition of the ingested carbon; \% plankton: proportion of total living carbon in the water column. Prey abbreviations as in Fig. 1, except Diatoms, which includes centric and pennate diatoms

\begin{tabular}{|c|c|c|c|c|c|c|c|c|c|c|c|c|}
\hline & \multicolumn{3}{|c|}{ Summer } & \multicolumn{3}{|c|}{ Fall } & \multicolumn{3}{|c|}{ Winter } & \multicolumn{3}{|c|}{ Spring } \\
\hline & $\begin{array}{c}\text { Ingestion } \\
0.2-1.6\end{array}$ & diet & $\begin{array}{c}\% \\
\text { plankton }\end{array}$ & $\begin{array}{c}\text { Ingestion } \\
0.2-1.6\end{array}$ & diet & $\begin{array}{c}\% \\
\text { plankton }\end{array}$ & $\begin{array}{l}\text { Ingestion } \\
0.2-1.6\end{array}$ & $\begin{array}{c}\% \\
\text { diet }\end{array}$ & $\begin{array}{c}\% \\
\text { plankton }\end{array}$ & $\begin{array}{c}\text { Ingestion } \\
0.2-1.6\end{array}$ & $\begin{array}{l}\% \\
\text { diet }\end{array}$ & $\begin{array}{c}\% \\
\text { plankton }\end{array}$ \\
\hline Het $B$ & $76-4.30$ & 43 & 32 & $60-3.96$ & 33 & 33 & $59-3.90$ & 35 & 19 & $63-3.50$ & 35 & 24 \\
\hline Pro & $2-0.10$ & 1 & 1 & $9-0.60$ & 5 & 4 & $1-0.04$ & 0.4 & 1 & $1-0.02$ & 0.2 & 1 \\
\hline Syn & $74-4.20$ & 42 & 25 & $86-5.64$ & 47 & 20 & $37-2.42$ & 22 & 4 & $57-3.20$ & 32 & 14 \\
\hline Pic & $2-0.10$ & 1 & 4 & $2-0.12$ & 1 & 5 & $3-0.22$ & 2 & 9 & $2-0.10$ & 1 & 5 \\
\hline Nan & $11-0.60$ & 6 & 28 & $15-0.96$ & 8 & 25 & $20-1.32$ & 12 & 14 & $22-1.20$ & 12 & 33 \\
\hline Diatoms & $12-0.70$ & 7 & 7 & $7-0.48$ & 4 & 7 & $44-2.86$ & 26 & 49 & $11-0.60$ & 6 & 18 \\
\hline Din & $0.2-0.01$ & 0.1 & 1 & $1-0.04$ & 0.3 & 1 & $1-0.04$ & 0.4 & 1 & $2-0.10$ & 1 & 1 \\
\hline Cil & $2-0.10$ & 1 & 2 & $2-0.12$ & 1 & 4 & $2-0.11$ & 1 & 3 & $23-1.30$ & 13 & 4 \\
\hline Total & $176-11$ & & & $183-12$ & & & $169-11$ & & & $180-10$ & & \\
\hline
\end{tabular}

column appears to be caused by less efficient capture of phytoplanktonic cells than of the other prey groups in the water column. This is probably due to differences in the process of handling and particle incorporation by the pinacocytes, which can phagocytose large particles (Reiswig 1971). The lower efficiency on these groups may also be due to cell resistance to digestive enzymes (i.e. cellulose and siliceous walls), with these cells requiring longer exposure to digestive enzymes (Reiswig 1971).

Several previous studies have reported the ability of sponges to capture diatoms (Reiswig 1971, Frost 1981, Simpson 1984, Witte et al. 1997). However, knowledge of their importance as a food source is still limited. It has been reported that digestible particles are egested as fecal pellets while indigestible particles are egested
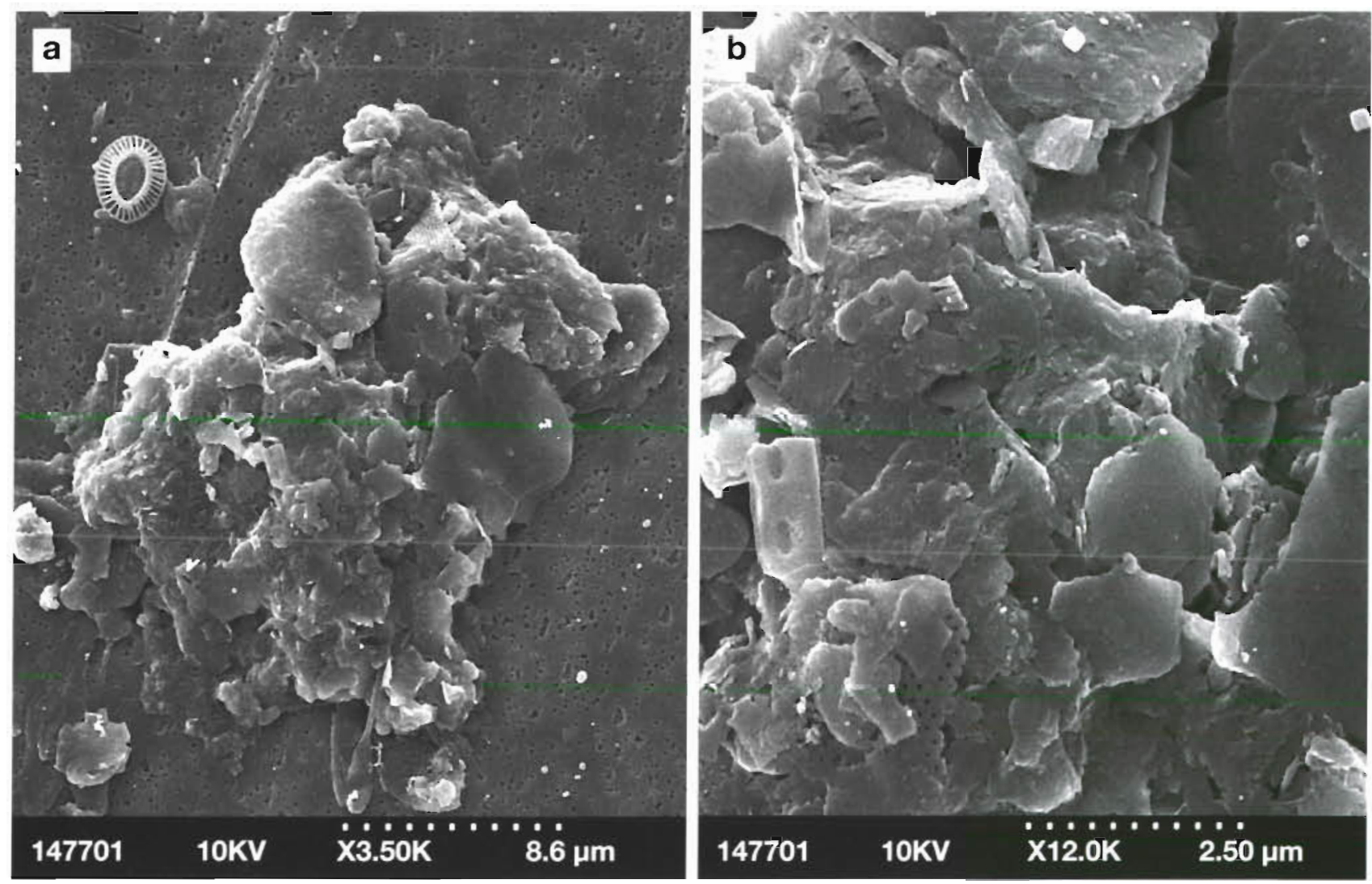

Fig. 4. SEM observations of the filters from the final incubation water samples. (a) Whole pseudopellet, $\times 3500$, and (b) detail of a pseudopellet showing several phytoplanktonic remains, $\times 12000$ 
as single particles (Wolfrath \& Barthel 1989). Therefore, the diatom remains observed inside the sponge and the large amounts of diatom and coccolithophoral fragments found in the pseudopellets suggest that the species is digesting these cells.

As a general feature of the sponge feeding system, pico- and nanoplankton are captured in the choanocytes, a particle capture system unique to sponges (Kilian 1952, Simpson 1984). Our results showed a higher clearance rate for picoplankton than for nanoplankton, suggesting higher retention efficiency for picoplankton. Selectivity in sponge feeding has some controversial points. Theoretically, the filterpump design implies that all water being pumped runs through the collar-filter (Larsen \& Riisgård 1994); hence, if all flow through the sponge has to pass through the collar-filter, it is difficult to postulate differences in retention rates. However, several studies estimating clearance rates based on the uptake of different prey sizes have observed that clearance rates varied among particle sizes, indicating differing retention efficiencies. This has been reported for tropical, temperate, and deep-sea sponges (Reiswig 1971, Pile et al. 1996, Turon et al. 1997, Witte et al. 1997), indicating that sponges are actively selecting particles, apparently during the handling process (Frost 1980, 1987).

Our experiments suggest that Dysidea avara does not significantly feed on POC of detrital origin or on DOC. Instead, it seems that the species was a net source of DOC. The ability to uptake DOC by sponges is evident when species have symbiotic bacteria but not so in nonsymbiotic species (Frost 1987). Our results agree with this general pattern, because $D$. avara is virtually free of bacterial symbionts (Turon et al. 1997).

Specific clearance rates exhibited a pattern of decreasing values with sponge size. Low filtration rates by large sponges could be attributable to refiltration of the water in the chamber. Due to the retention efficiencies reported for sponge species (between 75 and $99 \%$, Reiswig 1971, 1975, Wilkinson 1978, Pile et al. 1996), refiltration of water would imply practically full removal of food concentrations within the chamber. However, because the percentage decrease in prey concentration during the experiments was always less than $45 \%$ (Table 1), refiltration on its own does not explain the observed relationship between clearance rates and sponge size. Decreasing clearance rates with sponge size have previously been observed for other sponge species (Reiswig 1974, Frost 1980, Riisgård et al. 1993). Still, this general characteristic of metazoans has been accepted only cautiously for sponges (Riisgărd et al. 1993). Despite differing opinions about sponges as colonial organisms (Hartman \& Reiswig 1973, Simpson 1984), sponges are usually considered colonial animals (Jackson 1977, Frost et al. 1982), sug- gesting that their physiological capabilities should not change with size. However, sponge modules (canal system) are not clearly delimited and change continuously during the life of the sponge, and the rate of change probably depends on the species. This plasticity means that sponge shape is variable over time (Becerro et al. 1994). It has been suggested that the decrease in $C R_{\text {AFOW }}$ with sponge size could be the result of fewer living choanocytes per unit weight in large sponges (Riisgård et al. 1993). Nevertheless, the causes underlying this effect are still not well understood.

We did not observe any significant relationship between clearance rates and temperature over the range of temperatures in this study $\left(13\right.$ to $\left.22^{\circ} \mathrm{C}\right)$, which corresponded very closely to the annual temperature range in the study area $\left(12\right.$ to $\left.23^{\circ} \mathrm{C}\right)$. This is in contrast with the results of other authors who have observed increasing clearance rates with temperature (Riisgård et al. 1993: temperature range from 6 to $12^{\circ} \mathrm{C}$; Frost 1980: temperature range from 14 to $27^{\circ} \mathrm{C}$ ). The capacity for constriction-dilation of inhalant canals and/or choanocyte chambers has been proposed as a possible regulatory mechanism (Riisgård et al. 1993 and references therein). However, how this physical factor might affect sponge filtering activity remains unclear. Most of those studies examined the effect of temperature on clearance rates under laboratory conditions and with rather fast temperature changes (i.e. hours or a few days). Our experiments represent a different approach to the effect of temperature on clearance rates, because they were carried out with specimens that were always kept in their natural environment. Consequently, specimens had a slow, natural acclimation to each temperature through the seasons. Although our experimental set-up was not designed to test for the effect of temperature (a size effect may interfere with a potential temperature effect), our results suggest that under natural circumstances of gradual temperature change, clearance rates might be only slightly affected by temperature.

Pumping activity has been shown not always to be constant for all species (Reiswig 1971, Savarese et al. 1997). Several experiments carried out throughout the year to study respiration rates in Dysidea avara have shown no significant differences in respiration rate over diel cycles (Ribes unpubl. data). This would suggest a rather constant level of activity, as observed in the tropical demosponge Mycale sp. by Reiswig (1971). However, pumping without filtering has also been observed (Wilkinson et al. 1984). Consequently, whether or not filtering was constant cannot be determined from the incubation experiments, and the estimated clearance rates have to be regarded as average values.

The mean specific clearance rate estimated in this study was within the range of values reported for 
Dysidea avara with latex beads of $0.2,0.5$, and $1 \mu \mathrm{m}$ in the laboratory (Turon et al. 1997). Comparison of clearance rate values between species is difficult due to variability within each species and the effect of sponge size. Despite this, mean clearance rate values observed for this Mediterranean species were on the same order of magnitude as those estimated for the North Sea species Halicondria panicea, for the Norwegian-Greenland Sea species Therea muricata, and for most tropical species except Mycale sp., though values were among the lowest (Table 5). The high clearance rate for the tropical species Mycale sp. appears to be related to the fact that this species does not have symbionts. Therefore, because quantities of food in tropical seas are lower than in temperate zones, to obtain their energy requirements tropical species without symbionts might need to process larger volumes of water than species living in temperate seas.

Our results showed that the composition of the ingested carbon by Dysidea avara mainly varied according to the availability of the different prey types in the water column. During the winter months, the low values of grazing on heterotrophic bacteria and Synechococcus sp. were due to a drop off in bacterial biomass during the winter period (Ribes 1998), and the high values of grazing on phytoplankton were due to the winter phytoplankton bloom (Estrada et al. 1985). However, although highest live carbon abundance occurred during the winter period (Ribes 1998), food uptake during this period was not significantly higher (Table 4). This was probably due to the fact that during that period about $50 \%$ of the live carbon was provided by phytoplanktonic cells (Ribes 1998), for which retention efficiency is lower than for the other groups. The high grazing rates on pico- and nanoeucaryotes in May-June were due to an increase in the abundance of those groups during that period as well as to the higher retention efficiency for those species compared with phytoplanktonic cells. Therefore, pico- and nano- plankton provided a stable baseline of food for the species. However, the contribution of large cells such as phytoplankton was important in the energy budget of the sponge in some periods.

Resources have usually been considered a nonlimiting factor for sublittoral sponges (Reiswig 1974 . Becerro et al. 1994). Sponges survive in very foodlimited environments such as submarine caves and deep-sea communities, where they are also one of the dominant benthic groups (Riedl 1966, Gili et al. 1986, Gage \& Tyler 1991). Nevertheless, a linkage between food availability and secondary production by sponges has been demonstrated. Seasonal inputs of POC to the water have been suggested as a trigger for sexual reproduction in deep-sea sponges (Witte 1996), and both reduced current speeds and decreased food availability produce a reduction in growth (Wilkinson \& Vacelet 1979, Huysecom et al. 1988). Seasonal changes in toxicity observed in certain temperate sponges have also been related to seasonal changes in food availability (Turon et al, 1996). However, whether or not sponges are food-limited, the heterogeneous diet of Dysidea avara and its capacity to feed on a broad size spectrum of food sources allowed a rather constant level of food uptake to be maintained throughout the year. This feeding plasticity may represent an advantage for the species by attenuating the effects of seasonal fluctuations in planktonic communities, which have been reported to play an important role in determining the dynamics of suspension feeders in benthic communities in temperate seas (e.g. Bayne \& Newell 1983, Hawkins et al. 1985, Coma et al. 1998b). The plasticity in the trophic ecology of this species may be among the factors that enable it to be one of the most widespread temperate sponges (Atlantic: Lombas 1982; Mediterranean: Uriz et al. 1992), as well as to maintain high growth rates (Uriz et al. 1996). The plasticity of sponge trophic ecology may be among the main factors contributing to the worldwide abundance and distribution

Table 5. Specific clearance rates for various marine sponge species (ranges and mean values). DW: dry weight, AFDW: ash-free dry weight

\begin{tabular}{|c|c|c|c|c|}
\hline Species & Location & $\begin{array}{r}\text { Cle } \\
\mathrm{ml} \mathrm{g} \mathrm{DW} \mathrm{h}^{-1}\end{array}$ & $\begin{array}{l}\text { nce rate } \\
\mathrm{mlg} \text { AFDW }{ }^{-1} \mathrm{~h}^{-1}\end{array}$ & Source \\
\hline Dysidea avara & Mediterranean & $104-2046$ & $\begin{array}{c}264-4470 \\
1539 \pm 1241(\mathrm{SD})\end{array}$ & $\begin{array}{l}\text { This study } \\
\text { This study }\end{array}$ \\
\hline Dysidea avara & Mediterranean & $1391-3806$ & - & Turon et al (1997) \\
\hline Halichondria panicea & North Sea & - & $1700-5200$ & Riisgård et al. (1.993) \\
\hline Therea muricata & Norwegian-Greenland Sea & - & $5000-9000$ & Witte et al. (1997) \\
\hline Haliclona anonyma & South Africa & 5660 & & Stuart \& Klumpp (1984) \\
\hline Mycale sp. & Tropical & - & 12360 & Reiswig (1974) \\
\hline Tethya crypta & Tropical & - & 5353 & Reiswig $(1973,1974)$ \\
\hline Verongula sp. & Tropical & - & 3054 & Reiswig (1974) \\
\hline Verongia fistularis & Tropical & - & 3150 & Reiswig (1981) \\
\hline
\end{tabular}


of sponges despite large spatial and temporal variations in food sources. However, the role of trophic plasticity in determining the ecological success of suspension feeders is an issue requiring further study.

Acknowledgements. The authors especially thank Mikel Zabala and Enric Saiz for their help with this study. The manuscript was improved by the comments of $M$. Jesus Uriz, Xavier Turon, Quim Garrabou, Ken Sebens, Roger Hughes and 2 anonymous reviewers. Joandomènec Ros' comments on an earlier version of this manuscript and Emma Cebrian's help with phytoplankton counts are appreciated. Flow cytometry facilities were provided by the University of Hawai'i with the assistance of Hector Nolla. SEM observations were assisted by Jose-Manuel Fortuño. POC and DOC analyses were performed by the Scientist Technical Service (University of Barcelona) with the assistance of $I$. Casals, P. Fernandez, and L. Balart. Support for this work was provided by an F.P.I. fellowship from the Spanish Ministry of Education and Science to M.R., by a MEC research contract to R.C., a CICYT grant PB94-0014-C02-01, and the MAST-III-ELOISE European Union METRO MED Project.

\section{LITERATURE CITED}

Bayne BL, Newell RC (1983) Physiological energetics of marine molluscs. In: Saleuddin ASM, Wilbur KM (eds) The Mollusca, Vol 4. Physiology, part 1. Academic Press, New York, p 407-515

Becerro MA, Uriz MJ, Turon X (1994) Trends in space occupation by the encrusting sponge Crambe crambe: variation in shape as a function of size and environment. Mar Biol 121:301-307

Bjørnsen PK (1986) Automatic determination of bacterioplankton biomass by image analysis. Appl Environ Microbiol 51:1199-1204

Boero F, Balduzzi A, Bavestrello G, Caffa B, Vietti R (1986) Population dynamics of Eudendrium glomeratum (Cnidaria, Anthomedusae) on the Portofino promontory (Ligurian Sea). Mar Biol 92:81-85

Campbell L, Nolla N, Vaulot D (1994) The importance of Prochlorococcus to community structure in the central North Pacific Ocean. Limnol Oceanogr 39:954-961

Cloern JE (1982) Does the benthos control phytoplankton biomass in the south San Francisco estuary? Mar Ecol Prog Ser 9:191-202

Coma R, Gili JM, Zabala M, Riera T (1994) Feeding and prey capture cycles in the aposymbiotic gorgonian Paramuricea clavata. Mar Ecol Prog Ser 115:257-270

Coma R, Llobet I, Gili JM. Zabala M (1996) Quantification of sexual reproduction in the marine benthic hydrozoan Campanularia everta. Mar Biol 125:365-373

Coma R, Ribes $M$, Gili JM, Zabala M (1998a) An energetic approach to the study of life-history traits of two modular colonial benthic invertebrates. Mar Ecol Prog Ser 162: $89-103$

Coma R, Ribes M, Gili JM, Zabala M (1998b) Growth in a modular colonial marine invertebrate. Estuar Coast Shelf Sci 47:459-470

Conover RJ (1981) Nutritional strategies for feeding on small suspended particles. In: Longhurst AR (ed) Analysis of marine ecosystems. Academic Press, London, p 363-395

Crisp DJ (1984) Energy flow measurements. In: Holme NA, McIntyre AD (eds) Methods for the study of marine ben- thos. IBP Handbook 16, Blackwell Scientific Publications, Oxford, p 284-372

Edler L (1979) Recommendations for marine biological studies in the Baltic sea. Phytoplankton and chlorophyll. Baitic Mar Biol 5:5-38

Estrada M, Vives F, Alcaraz M (1985) Life and productivity of the open sea. In: Margalef R (ed) Western Mediterranean. Pergamon Press, London, p 148-197

Frost TM (1980) Clearance rate determinations for the freshwater sponge Spongilla lacustris: effects of temperature, particle type and concentration, and sponge size. Arch Hydrobiol 90:330-356

Frost TM (1981) Analysis of ingested particles within a freshwater sponge. Trans Am Microsc Soc 100:271-277

Frost TM (1987) Porifera. In: Pandian TJ, Vernberg FJ (eds) Animal energetics, Vol 1 Academic Press, London, p $27-53$

Frost TM, DeNagy GS, Gilbert JJ (1982) Population dynamics and standing biomass of the freshwater sponge Spongilla lacustris. Ecology 63:1203-1210

Fry JC (1988) Determination of biomass. In: Austin B (ed) Methods in aquatic bacteriology. Wiley and Sons, New York, p 27-72

Gage JD, Tyler PA (1991) Deep-sea biology. A natural history of organisms at the deep-sea floor. Cambridge University Press, Cambridge

Gaino E, Bavestrello G, Cattaneo-Vietti R, Sarà M (1994) Scanning electron microscope evidence for diatom uptake by two Antarctic sponges. Polar Biol 14:55-58

Gili JM, Coma R (1998) Benthic suspension feeders: their paramount role in littoral marine food webs. Trends Ecol Evol 13:316-321

Gili JM, Riera T, Zabala M (1986) Physical and biological gradients in a submarine cave on the Western Mediterranean coast. Mar Biol 90:291-297

Griffiths CL, Griffiths RJ (1987) Bivalvia. In: Pandian TJ, Vernberg FJ (eds) Animal energetics, Vol 2. Academic Press, London, p 1-88

Hartman WD, Reiswig HM (1973) The individuality of sponges. In: Boardman RS, Cheetham $\mathrm{AH}$, Oliver WA (eds) Animal colonies. Hutchison and Ross, Stroudsburg, PA, p 567-584

Hawkins AJS, Salkeld PN, Bayne BL, Gnaiger E, Lowe DM (1985) Feeding and resource allocation in the mussel Mytilus edulis: evidence for time-averaged optimization. Mar Ecol Prog Ser 20:273-287

Huysecom J, Richelle-Maurer E, van de Vyver G, Vray B (1988) Effects of bacterial concentration on the retention and growth rate of the freshwater sponge Ephydatia fluviatilis. Physiol Zool 6:535-542

Jackson JBC (1977) Competition on marine hard substrata: the adaptative significance of solitary and colonial strategies. Am Nat 111:743-767

Kana T, Glibert PM (1987) Effect of irradiances up to $2000 \mu \mathrm{E}$ $\mathrm{m}^{-2} \mathrm{~s}^{-2}$ on marine Synechococcus WH 7803-I. Growth, pigmentation, and cell composition. Deep-Sea Res 34: $479-516$

Kilian EF (1952) Wasserströmung und Nahrungsaufnahme beim Süsswasserschwämmen Ephydatia fluviatilis. Z Vgl Physiol 34:407-447

Kimmerer WJ, Gartside E, Orsi JJ (1994) Predation by an introduced clam as the likely cause of substantial declines in zooplankton in San Francisco Bay. Mar Ecol Prog Ser 113:81-93

Larsen PS, Riisgård HU (1994) The sponge pump. J Theor Biol 168:53-63

Llobet I, Gili JM, Hughes RG (1991) Horizontal, vertical and 
seasonal distribution of epiphytic hydrozoa on the alga Halimeda tuna in the Northwestern Mediterranean Sea. Mar Biol 110:151 - 159

Lombas I (1982) Distribución de esponjas esciáfilas en la zona intermareal de aramar (Luanco, Asturias). Bol. Cienc Nat IDEA 29:37-50

Massana R, Gasol JM, Bjørnsen PK, Blackburn N, Hagström A. Hietanen S, Hygum J, Kuparinen BHK, Pedrós-Alió C (1997) Measurement of bacterial size via image analysis of epifluorescence preparations: description of an inexpensive system and solutions to some of the most common problems. Sci Mar 61:397-407

Monger BM, Landry MR (1993) Flow cytometric analysis of marine bacteria with Hoeschst 33342. Appl Environ Microbiol 59:905-911

Montagnes DJ, Berges SJA, Harrison PJ, Taylor FJR (1994) Estimating carbon, nitrogen, protein and chlorophyll a from volume in marine phytoplankton. Limnol Oceanogr 39:1044-1060

Officer CB, Smayda TJ, Mann R (1982) Benthic filter feeding: a natural eutrophication control. Mar Ecol Prog Ser 9:203-210

Pile AJ, Patterson MR, Witman JD (1996) In situ grazing on plankton <10 $\mu \mathrm{m}$ by the boreal sponge Mycale lingua. Mar Ecol Prog Ser 141:95-102

Pile AJ, Patterson MR, Savarese M, Chernykh VI, Fialkov VA (1997) Trophic effects of sponge feeding within Lake Baikal's littoral zone. 2. Sponge abundance, diet, feeding efficiency, and carbon flux. Limnol Oceanogr 42:178-184

Putt M, Stoecker DK (1989) An experimentally determined carbon volume ratio for marine 'oligotrichous' ciliates from estuarine and coastal waters. Limnol Oceanogr 34:1097-1103

Reiswig HM (1971) Particle feeding in natural populations of three marine demosponges. Biol Bull 141:568-591

Reiswig HM (1973) Population dynamics of three Jamaican Demospongiae. Bull Mar Sci 23:191-226

Reiswig HM (1974) Water transport, respiration and energetics of three tropical marine sponges. J Exp Mar Biol Ecol $14: 231-249$

Reiswig HM (1975) Bacteria as food for temperate-water marine sponges. Can J Zool 53:582-589

Reiswig HM (1981) Partial carbon and energy budgets of the bacteriosponge Verongia fistularis (Porifera: Desmospongiae) in Barbados. PSZN I: Mar Ecol 2:273-293

Ribes $M$ (1998) Feeding activity and diet of benthic suspension feeders related to metabolic requirements and seston composition. PhD thesis, Univ Barcelona

Ribes M, Coma R. Gili JM (1998a) Heterotrophic feeding by gorgonian corals with symbiotic zooxanthellae. Limnol Oceanogr 43:1170-1179

Ribes M, Coma R, Gili JM (1998b) Seasonal variation of in situ feeding rates by the temperate ascidion Halocynthia papillosa. Mar Ecol Prog Ser 175:201-213

Riedl R (1966) Biologie der Meereshöhlen. Paul Parey, Hamburg

Rijsgård HU, Thomassen S, Jakobsen $\mathrm{H}$, Weeks JM, Larsen PS (1993) Suspension feeding in marine sponges Halichondria panicea and Haliclona urceolus: effects of temperature on filtration rate and energy cost of pumping Mar Ecol Prog Ser 96:177-188

Savarese M, Patterson MR, Chernykh VI, Fialkov VA (1997) Trophic effects of sponge feeding within Lake Baikal's littoral zone. I. In situ pumping rates. Limnol Oceanogr 42:171-178

Schmidt I (1970) Phagocytose et pinocytose chez les Spongillidae. Z Vgl Physiol 66:398-420

Simon M, Azam F (1989) Protein content and protein synthesis rates of planktonic marine bacteria. Mar Ecol Prog Ser
$51: 201-213$

Simpson TL (1984) The cell biology of sponges. SpringerVerlag, New York

Sokal RR, Rohlf FJ (1981) Biometry, 2nd edn. Freeman, San Francisco

Stuart V, Klumpp DW (1984) Evidence for food-resource partitioning by kelp-bed filter feeders. Mar Ecol Prog Ser $16: 27-37$

Turon X, Becerro MA (1992) Growth and survival of several ascidian species from the northwestern Mediterranean. Mar Ecol Prog Ser 82:235-247

Turon X, Becerro MA, Uriz MJ (1996) Seasonal patterns of toxicity in benthic invertebrates: the encrusting sponge Crambe crambe (Poecilosclerida). Oikos 75:33-40

Turon X, Galera J, Uriz MJ (1997) Clearance rates and aquiferous systems in two sponges with contrasting life-history strategies. J Exp Zool 278:22-36

Uriz MJ, Rosell D, Martín D (1992) The sponge population of the Cabrera archipelago (Balearic Islands): characteristics, distribution and abundance of the most representative species. PSZN I: Mar Ecol 113:101-117

Uriz MJ, Turon X, Becerro MA, Galera J (1996) Feeding deterrence in sponges. The role of toxicity, physical defenses, energetic contents and life-history stage. J Exp Mar Biol Ecol 205:187-204

Vacelet J, Boury-Esnault $N$ (1995) Carnivorous sponges. Nature 373:333-335

Valentin J (1972) La ponte et les oeufs chez les copépodes du golfe de Marseille: cycle annuel et étude expérimentale. Tethys 4:349-390

van der Vyver G, Vray B, Belaouane S, Touussaint D (1990) Efficiency and selectivity of microorganism retention by Ephydatia fluviatilis. In: Rützer K (ed) New perspectives in sponge biology. Smithsonian Institution Press, Washington, DC, p 511-515

Vaulot D, Partensky F, Neveus J, Mantoura RFC, Llewellyn C (1990) Winter presence of prochlorophytes in surface waters of the northwestern Mediterranean Sea. Limnol Oceanogr 35:1156-1164

Verity PG, Robertson CY, Tronzo CR, Andrews MG, Nelson JR, Sieracki ME (1992) Relationships between cell volume and the carbon and nitrogen content of marine photosynthetic nanoplankton. Limnol Oceanogr 37:1434-1446

Wilkinson CR (1978) Microbial associations in sponges. I. Ecology, physiology and microbial populations of coral reef sponges. Mar Biol 49:161-167

Wilkinson CR, Vacelet J (1979) Transplantation of marine sponges to different conditions of light and current. J Exp Mar Biol Ecol 37:91-104

Wilkinson CR, Garrone R, Vacelet J (1984) Marine sponges discriminate between food bacteria and bacterial symbionts: electron microscope radioautography and in situ evidence. Proc R Soc Lond 220:519-528

Witte U (1996) Seasonal reproduction in deep-sea sponges-triggered by vertical particle flux? Mar Biol 124:571-581

Witte UT, Brattegard T, Graf $G$, Springer B (1997) Particle capture and deposition by deep-sea sponges from the Norwegian-Greenland Sea. Mar Ecol Prog Ser 154:241-252

Wolfrath B, Barthel D (1989) Production of faecal pellets by the marine sponge Halichondria panicea Pallas (1766). J Exp Mar Biol Ecol 129:81-94

Zabala M (1983) Estudi sistemàtic i faunistic dels briozous (Ectoprocta) dels Paissos Catalans. PhD thesis, Univ Barcelona

Zabala M, Ballesteros E (1989) Surface-dependent strategies and energy flux in benthic marine communities or why corals do not exist in the Mediterranean. Sci Mar 53:3-17 